\title{
Ageing in Southeast and East Asia
}


The Institute of Southeast Asian Studies (ISEAS) was established as an autonomous organization in 1968. It is a regional centre dedicated to the study of socio-political, security and economic trends and developments in Southeast Asia and its wider geostrategic and economic environment.

The Institute's research programmes are the Regional Economic Studies (RES, including ASEAN and APEC), Regional Strategic and Political Studies (RSPS), and Regional Social and Cultural Studies (RSCS).

ISEAS Publishing, an established academic press, has issued almost 2,000 books and journals. It is the largest scholarly publisher of research about Southeast Asia from within the region. ISEAS Publishing works with many other academic and trade publishers and distributors to disseminate important research and analyses from and about Southeast Asia to the rest of the world. 


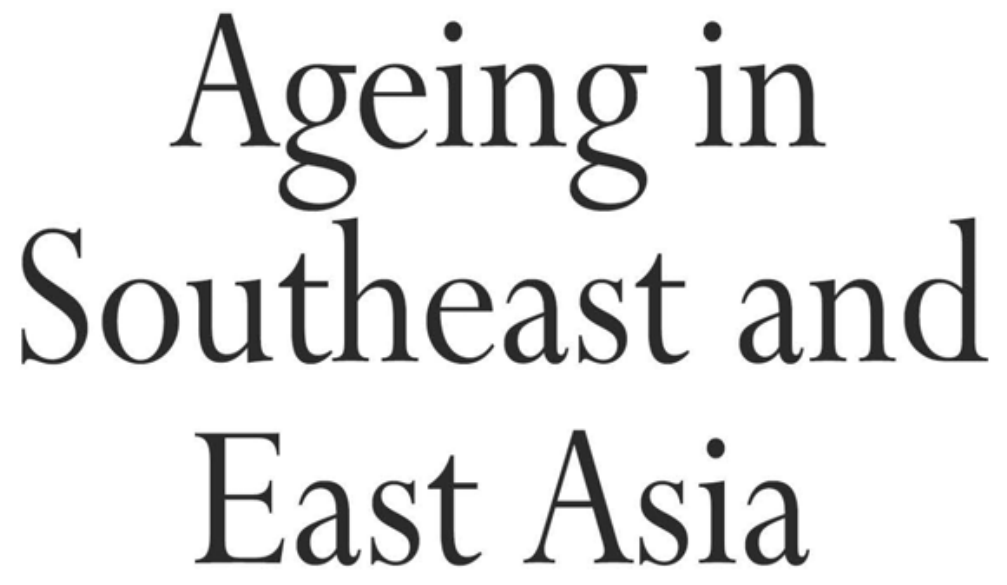

Family, Social Protection and Policy Challenges

\author{
EDITED BY \\ LEE HOCK GUAN
}

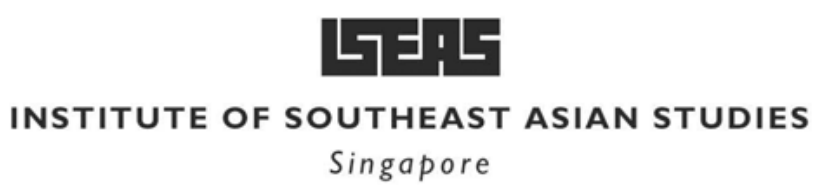


First published in Singapore in 2008 by

Institute of Southeast Asian Studies

30 Heng Mui Keng Terrace

Pasir Panjang

Singapore 119614

E-mail: publish@iseas.edu.sg

Website: <http://bookshop.iseas.edu.sg>

All rights reserved. No part of this publication may be reproduced, stored in a retrieval system, or transmitted in any form or by any means, electronic, mechanical, photocopying, recording or otherwise, without the prior permission of the Institute of Southeast Asian Studies.

(C) 2008 Institute of Southeast Asian Studies, Singapore

The responsibility for facts and opinions in this publication rests exclusively with the authors and their interpretations do not necessarily reflect the views or the policy of the publisher or its supporters.

\section{ISEAS Library Cataloguing-in-Publication Data}

Ageing in Southeast \& East Asia : family, social protection, policy challenges / edited by Lee Hock Guan.

"The Chapters in this volume are selected from papers delivered at a two-day workshop, titled Ageing and the Status of the Older Population in Southeast Asia, organized by ISEAS from 22 to 23 November 2004"-Acknowledgement.

1. Aging-Government policy-Southeast Asia-Congresses.

2. Aging-Government policy-East Asia_Congresses.

3. Older people-Southeast Asia-Economic conditions-Congresses.

4. Older people-East Asia-Economic conditions-Congresses.

5. Older people-Southeast Asia-Social conditions-Congresses.

6. Older people-East Asia-Social conditions-Congresses.

I. Lee Hock Guan.

II. Institute of Southeast Asian Studies.

III. Workshop on Ageing and the Status of the Older Population in Southeast Asia (2004 : Singapore)

IV. Title: Ageing in Southeast and East Asia

HQ1064 A8A263 2008

ISBN 978-981-230-765-1 (soft cover)

ISBN 978-981-230-766-8 (hard cover)

Typeset by Superskill Graphics Pte Ltd

Printed in Singapore by Photoplates Private Limited 